\title{
Physical Activity in Mathematics Education
}

By Friederike Bayer \& Thomas Rottmann

Korrekt citering af denne artikel efter APA-systemet

(American Psychological Association System, 6th Edition):

Bayer, F. \& Rottmann, T. (2018). Physical Activity in

Mathematics Education. Learning Tech - Tidsskrift for læremidler,

didaktik og teknologi, (4), 66-93. DOI: 10.7146/lt.v4i4.110494 


\section{Abstract}

"Læring gennem fysisk aktivitet" bruges til at beskrive den læringsproces, hvor hel-krops-bevægelser er stærkt knyttet til læringsindholdet. Selvom denne måde at lære på er almindeligt accepteret, og dens positive indvirkning på læringsprocessen er teoretisk begrundet - så mangler idéer til den praktiske anvendelse i matematikundervisningen i Tyskland stadig, og det gør den videnskabelige forskning på dette område også. Denne artikel har til formål at lukke dette forskningsgab. For at støtte udviklingen af "Grundvorstellungen" af multiplikation, blev bevægelsesspil udviklet og videnskabeligt evalueret. Projektet blev gennemført via en forudgående test på en blandet aldersgruppe. Der var særlig fokus på elever med indlæringsvanskeligheder i matematik. Denne artikel klassificerer begrebet "Læring gennem fysisk aktivitet" og giver indsigt i det matematiske begreb for "Grundvorstellungen" af multiplikation. De designede bevægelsesspil og det udviklede diagnostiske værktøj præsenteres i denne artikel. Desuden er resultaterne af de eksplorative studier samt perspektiver for fremtidige studier for læring beskrevet.

The term "Learning through Physical Activity" is used to describe learning processes in which whole-body movement is strongly linked to the learning content. Although this way of learning is generally accepted and its positive impact on the learning process is theoretically grounded, ideas for the practical application in mathematics education in Germany are largely missing, as is any corresponding scientific research. This paper aims to close this research gap. In order to do so, movement games, which support the development of "Grundvorstellungen" of multiplication, were developed and scientifically evaluated using a pre- and post-test design during a teaching unit in a mixed-age group. Particular focus was given to students with learning difficulties in mathematics. This paper contextualises the term Learning through Physical Activity and gives an insight into the mathematical concept of Grundvorstellungen of multiplication. The designed movement games, as well as the developed diagnostic tool, are presented in this paper. Furthermore, the results of the exploratory study and perspectives for further teaching studies are described. 


\section{Physical Activity in Mathematics Education}

\section{Developing "Grundvorstellungen" of Multiplication by Learning through Physical Activity}

\section{Introduction}

In recent years, a growing body of research provides evidence for the importance of bodily grounded experiences, e.g. in the form of whole-body movement, to learning processes (see the review of research literature by Tran, Smith \& Buschkuehl, 2017). In Germany, approaches for implementing physical activity into learning activities - especially in schools - are labelled as "Bewegtes Lernen" (Müller, 2003; Thiel, Teubert \& KleindienstCachay, 2006).

In general, two forms of Bewegtes Lernen can be distinguished with respect to the different role of physical activity in the learning process: either the movement accompanies the learning process in time but not in content (labelled as "Learning in Physical Activity"), or the action of the movement is directly related to the learning content (labelled as "Learning through Physical Activity"). In a similar sense, Tran et al., (2017) differentiate between "movement that is closely related to mathematical content" and "movement for the sake of fitness or motivation" (Tran et al., 2017, p. 13). In German-speaking regions many practical teaching ideas and scientific evidence for Learning in Physical Activity have been developed, but very few for Learning through Physical Activity - although this form can be theoretically corroborated by different disciplines and is considered more substantial.

This exploratory study deals with the previously underrepresented domain of Learning through Physical Activity in mathematics education. "Movement games", in which students learn a mathematical content through physical activity, were designed and implemented in a mixed-age group of first and 
second graders. The concept of multiplication was chosen as an appropriate mathematical content for all movement games. The learning development of the participating students was evaluated using a pre- and post-test design with a special focus on students with difficulties in learning mathematics.

During the planning phase, special emphasis was placed on the interdisciplinary cooperation between the didactics of mathematics and sports pedagogy. Both disciplines are important for designing movement games, which need to satisfy both requirements for effective teaching of mathematical content and success as a game from the perspective of sports didactics. At the same time, movement games should convey the enjoyment of physical activity, foster motor abilities and support mathematical learning development.

This pilot study aims to develop, implement, and evaluate movement games which foster the development of a conceptual understanding of multiplication, and thereby intents to build the foundation for further research in this domain. Therefore, apart from testing the diagnostic tool and the movement games, the main research interest of this exploratory study is to analyse, to what extent children's conceptual understanding of multiplication could be fostered by Learning through Physical Activity.

\section{Learning in Physical Activity}

To clarify the central ideas of Learning through Physical Activity, we start with a short description of Learning in Physical Activity to contrast both approaches. Learning in Physical Activity means that movement is linked on a temporal level with the learning content. This theory takes two forms: Either students exercise while learning, without any content-related connection with the learning object (e.g. running dictation: a student runs to a table with a written sentence placed on top of it, reads the sentence and remembers it while running back to the work place to write the sentence from memory); or the learning process is interrupted by an activity involving whole-body movement (e.g. a running break in which the students interrupt their learning with a run and continue with their work afterwards (Beckmann \& Riegel, 2014, p. 6)). The movement is usually employed with the aim of fostering the learning process by improving the ability to concentrate (Baur-Fettah, 2007, p. 188). Research results confirm this connection. Physical activity raises the blood flow in cer- 
tain brain regions, which is accompanied by an increase in the exchange of oxygen and nutrients, and as a result, shows positive effects on the ability to concentrate (Voll \& Buuck, 2005, p. 1).

Several empirical studies have investigated this neurophysiologically confirmed relationship in school settings by examining the influence of body movements on concentration and/or academic performance, while also taking into account various factors (e.g. age, type of movement, [effect] duration). Although meta-analyses of scientific literature does not show a completely consistent picture, the majority of studies detect a moderately positive relationship between physical activity and cognitive functioning or academic performance (Fleig, 2008; Rasberry et al., 2011; Sibley \& Etnier, 2003). In addition, neurophysiological evidence suggests that physical activity induces changes in the hippocampus - an area of the brain that is important for learning because it helps to transfer knowledge into long-term memory (Voll \& Buuck, 2005, p. 2).

\section{Learning through Physical Activity}

In addition to the general benefits of physical activities accompanying the learning process in time, a direct connection between the movement and the learning content itself provides further opportunities to support academic learning. In mathematics education the role of activities in learning mathematical concepts is intensively discussed. However, the main focus in this discussion is on fine motor activity with respect to using concrete (didactical) material (McNeil \& Uttal, 2009; Uttal, Scudder \& DeLoache, 1997). The discussion about the role of concrete material and related actions is strongly influenced by the theory of Piaget (1970) and Bruner (1966; 1973). Piaget (1970) closely links the use of material to an early stage of general cognitive development: as young children are incapable of abstract thought, they need concrete experiences with manipulatives. These concrete actions establish the basis for the development of mental operations. In a departing from connecting the use of concrete material to a specific cognitive stage, Bruner (1966) regards processes of internalization as crucial for the cognitive development at all levels. According to his theory, children develop new concepts within a process of internalization passing through three phases: "from (a) acting on concrete objects to (b) forming images of the con- 
crete constructions to (c) adopting symbolic notations" (McNeil \& Uttal, 2009, p. 138).

Without questioning the relevance of using manipulatives in general, Uttal, O’Doherty, Newland, Liu Hand \& DeLoache (2009) point out that there is no direct route from concrete material to mathematical concepts. Connecting concrete and symbolic representations turns out to be very challenging.

9

Several studies have shown that the use of concrete objects can indeed facilitate the acquisition of conceptual knowledge in a variety of mathematical domains [...]. But children often fail to transfer what they learn from manipulatives to other forms of representation, including written, symbolic representations [...]. (Uttal et al., 2009, p. 158)

An important prerequisite for successful internalization seems to be the child's "reflection" of the concrete activity performed (Simon et al., 2010). In this context, Tzur (2007) considers "a mental mechanism of reflection on activity-effect relationship" (Tzur, 2007, p. 275) as crucial for the development of new mathematical concepts. A conscious focus on essential aspects of an activity can provide a basis for replacing physical actions with concrete material by mental actions only.

Compared to the use of manipulatives, whole-body movements imply a higher intensity of motoric engagement and, therefore, have additional benefits, as gross motor activities address an additional information channel. Beyond providing auditory and visual information, the kinaesthetic information channel is activated by whole-body movements and offers supplementary access to the learning content. The body is used to receiving information; as such, children are enabled to physically grasp the learning content (Baur-Fettah, 2007). Another benefit is that knowledge storage is enhanced when the more perceptual channels are activated (Weidenmann, 2009).

However, there has been very little research so far on the impact of whole-body movements on mathematical learning, particularly in terms of intervention studies. The studies almost exclusively deal with number concepts (e.g. using number lines to teach counting, magnitude, etc.). A review of research literature in this domain shows inconsistent results (Tran et al., 2017). Although children benefit from embodied approaches, it is not 
possible to substantiate clear advantages compared to other approaches.

For students with learning difficulties, Bewegtes Lernen can be considered promising, because physical activity prevents concentration difficulties and provides access to new learning opportunities. Accordingly, the findings of Link, Moeller, Huber, Fischer \& Nuerk (2015) suggest that students experiencing difficulties in spatial representation of number magnitude benefit more from a training of this content based on whole-body movement than other students.

\section{Understanding of Multiplication}

Compared to addition and subtraction, learning multiplication is highly demanding for students and requires more abstract thinking (Barmby, Harries, Higgins \& Suggate, 2009; Downton \& Sullivan, 2017; Larsson, Pettersson \& Andrews, 2017).

99

Whilst addition and subtraction can be thought of as the joining of sets, multiplication is about replication. Addition and subtraction are unary operations with each input representing the same kind of element [...]. However, we need to view multiplication as a binary operation with two distinctive inputs. (Barmby et al., 2009, p. 218)

In a multiplication task the two numbers involved have different meanings and play different roles. With regard to repeated addition, in " $3 \cdot 4$ " the numeral " 4 " represent the number of elements in each set, while the numeral " 3 " stands for the number of sets.

Understanding multiplication and the development of multiplicative thinking are among the most important learning objectives in primary arithmetic and form the basis for learning mathematical concepts and contents like ratio, fractions and probability (Downton \& Sullivan, 2017). Therefore, the development of Grundvorstellungen of multiplication is essential for further learning processes.

\section{The Concept of Grundvorstellungen}

The German term Grundvorstellungen ("basic ideas"; GVs) is frequently used in the context of developing mathematical concepts. GVs can be considered as mediators between reality,

71 Learning Tech 04 | Fagdidaktiske studier i historie, fremmedsprog og matematik 
mathematical concepts and learners' individual images or mental models (Kleine, Jordan \& Harvey, 2005; vom Hofe \& Blum, 2016).

99

Grundvorstellungen can be construed as mediating elements or as objects of transition between the world of mathematics and the individual conceptual world of the learner. GVs thus describe relationships between mathematical structures, individual-psychological processes, and subject-related contexts, or, in short: the relationships between mathematics, the individual, and reality.

(vom Hofe \& Blum, 2016, p. 231)

In this sense, GVs of mathematical concepts are relevant for transitions from real-life situations to mathematical models. For example, a child has to activate GVs of multiplication to solve a task such as "The price for one cup of coffee is $2 €$. How much is the price for 4 cups?" by transferring this word problem to the number fact " 4 times 2 ".

Wartha (2011) uses GVs in a more general way - in his view, GVs need to be activated for any kind of transition between different modes of representation. Accordingly, GVs of multiplication are also used when a child figures out a calculation task given in a symbolic form (e.g. " $3 \cdot 4$ ") by dealing with manipulatives like counters. The child has to transfer the symbolic representation to an appropriate activity to be performed with the counters by activating GVs of multiplication (e.g. as the concrete action of "putting together equal groups of elements", i.e., "three times four counters"). Finally, the child has to interpret the total number of elements (counters) as the result, which can be represented in a symbolic manner ("12"; see Figure 1).

\section{Grundvorstellungen of Multiplication}

With respect to multiplication, several aspects and related GVs can be distinguished. Greer (1992) describes four aspects:

(1) "equal groups"; (2) "multiplicative comparison"; (3) "rectangular area”; and (4) "Cartesian product”. Because of their minor role in introducing multiplication in schools, multiplicative comparison (e.g. "Tom has 3 cookies. Tim has 4 times as many cookies as Tom.") and Cartesian product (e.g. "Tim has 3 pairs of trousers and 4 shirts. How many different outfits are possible?") are not further discussed in this paper.

72 Learning Tech 04 | Fagdidaktiske studier i historie, fremmedsprog og matematik 


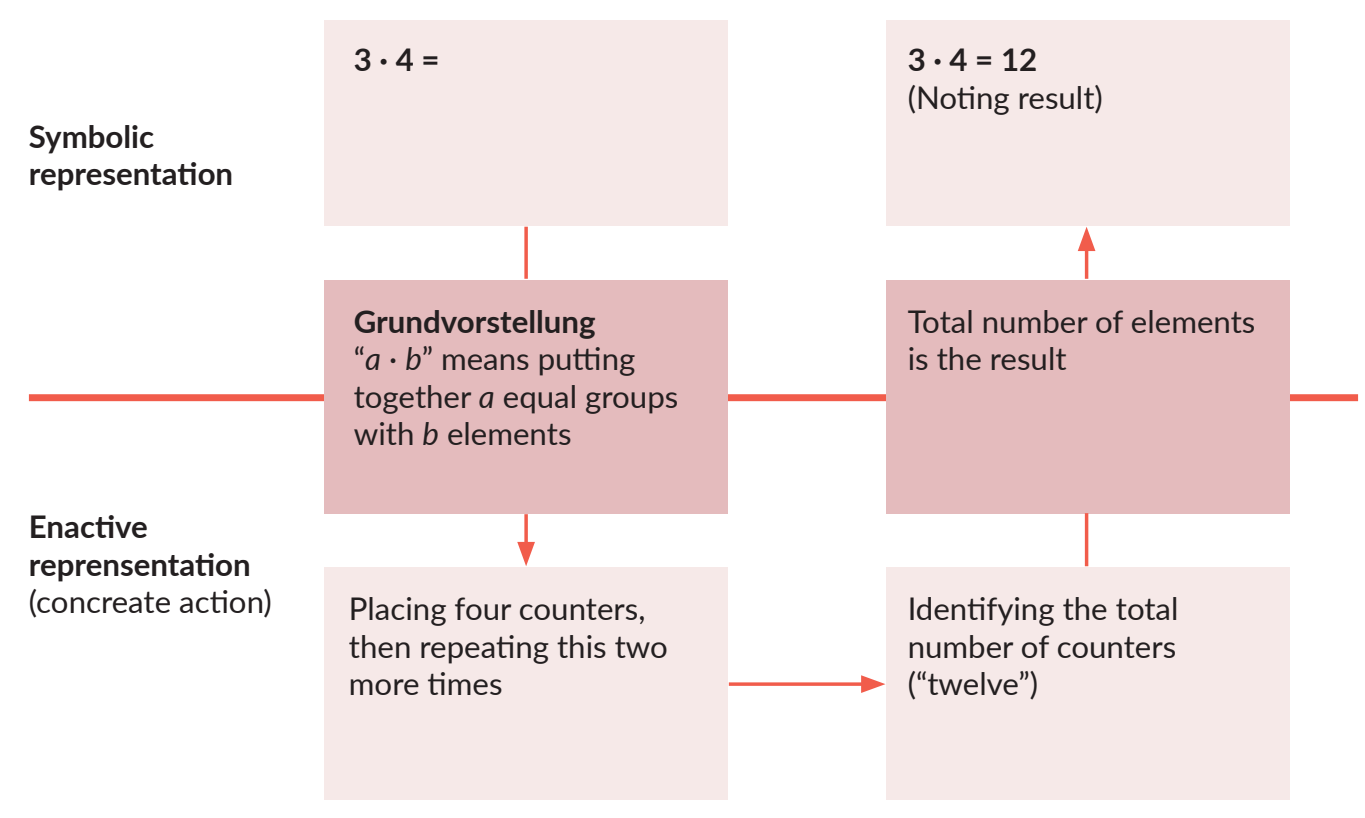

As a first encounter to multiplication, the aspect of equal groups is commonly used. In this sense, multiplication means repeated addition of equal addends, which can be considered as the "basic intuitive meaning of multiplication" (Schmidt \& Weiser, 1995, p. 66). Equal groups can be presented either in the form of a partwhole structure or in an iteration structure (Schmidt \& Weiser, 1995). In part-whole structure groups with an equal number of elements, each are presented simultaneously. The iteration structure is characterised by repeating an action; the groups are built up one by one. Both structures are closely connected to each other, as is apparent in Figure 2, s. 74. The iterative process of moving three chairs at a time, repeating this action four times, results in a simultaneous presentation of the part-whole structure with four times three chairs standing in a rectangular array.

Another interrelation between the different structures of multiplication can be illustrated with this example. The part-whole structure of equal-sized groups can be presented in different spatial configurations: while in Figure 2 the elements are arranged in a rectangular array, the same elements could easily be rearranged using different structures (e.g. "groups of three chairs, in each case organized around one of four tables"). Therefore, the rectangular area could also be interpreted as a 
Figure 2. Iconic representation of the task "4 - 3" (CWestermann Gruppe/illustrator: Martina Theisen).

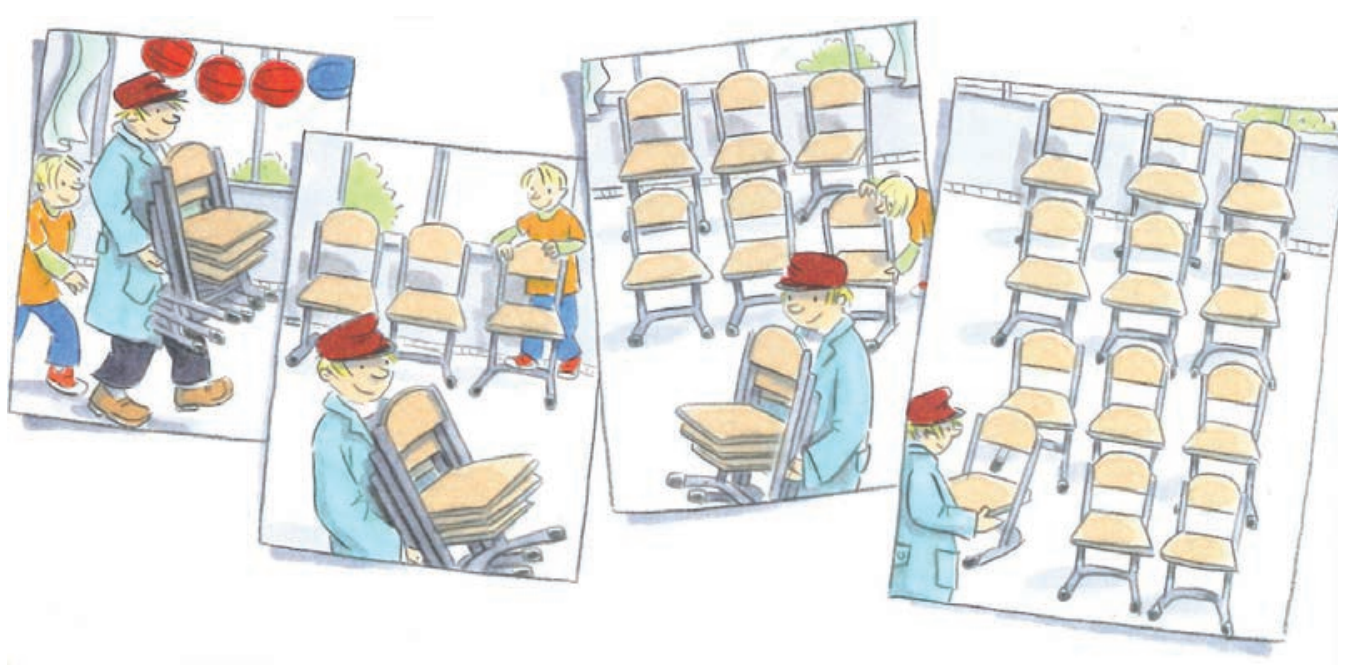

special case of equal groups with a part-whole structure instead of forming an independent aspect of multiplication (Schmidt $\&$ Weiser, 1995). The use of array-based materials is beneficial, particularly in order to visualise commutativity (e.g. " $3 \cdot 4=4 \cdot 3$ ") and to represent multiplication facts with multi-digit numbers or fractions (Barmby et al., 2009; Young-Loveridge \& Mills, 2009).

\section{Design of the Exploratory Study}

In order to gain insight into the potential effectiveness of Learning through Physical Activity, we developed movement games that were directly related to a mathematical learning content, as well as a diagnostic tool to assess the learning development. The development of GVs of multiplication in terms of equal groups was chosen as relevant learning content. The movement games were tested and evaluated in the form of an exploratory study in a German primary school with first and second graders, who were taught together in a mixed-age class. In total, the sample included 18 students of which five students were repeating a class due to learning difficulties. In total, seven students were classified as experiencing difficulties in mathematics learning by 
their mathematics teacher ${ }^{1}$, with two of them having special educational needs in learning. While the first graders had not been taught multiplication in class at the time of the study, the second graders had received a brief introduction. Due to the small sample size, this pilot study does not aim for generalizable results, but intends to provide the basis for further research projects by developing and initially evaluating both movement games and diagnostic tools.

The survey included six teaching units. To gain insight into the effect of movement games on GVs of multiplication, the diagnostic tool was conducted in the first and the last lesson in a preand post-test setting. The remaining four lessons were used to carry out the movement games in a gymnastic hall. Additionally, reflection phases were implemented after playing the games in order to direct the children's attention to the mathematical content involved. Two lessons were taken from the regular mathematics and sports lessons. Both the diagnostic tool and the lessons were conducted by the first author. Apart from these units, there was no teaching of multiplication in regular lessons.

In addition, participatory observations were made to gain further information about the practicability of the movement games, the appropriateness of the difficulty level of the tasks and the comprehensibility of the reflection phases. These observations influenced the detailed planning of the subsequent lessons, for example, in adapting the number of repetitions of a game.

The following research questions were used to guide the data analysis:

To what extent does Learning through Physical Activity influence the development of GVs of multiplication?

\section{To what extent does the identified development also apply to students with learning difficulties in mathematics?}

1 The assessment by the mathematics teacher is based on the current performance in the field of arithmetic in written assignments.

75 Learning Tech 04 | Fagdidaktiske studier i historie, fremmedsprog og matematik 


\section{Movement Games to Develop Grundvorstellungen of Multiplication}

Typical game concepts from physical education ("Reversal Relay Race"2, "Atomic Game"3) as well as mathematical didactic material (e.g. number lines) were the starting points for the conception of the movement games. Three basic game concepts were designed, "Jumping Along the Number Line", "Multiplicative Relay Race" and "Multiplicative Atomic Game". Each movement game focuses on one aspect of multiplication in terms of equal groups. While the Multiplicative Atomic Game mainly promotes the partwhole structure, Jumping Along the Number Line focuses on the iteration aspect. The main idea of the Multiplicative Relay Race is to connect both aspects.

Three aspects underpin the design of the movement games. First, the whole-body motion should directly correspond to the mathematical content, which means that students can understand the learning content through the physical activity. Second, the movement should be described and reflected in order to build "an anticipated (invariant) relationship between an activity and its effect" (Tzur, 2007, p. 275). To foster children's reflection of the physical activity both partner work and discussions of the results and observations of the movement games were implemented. Third, there should be a balanced proportion between physical and cognitive activity. Therefore, each game was adapted to take into account the perspective of mathematical didactics as well as sports pedagogy. Both perspectives were considered equally in the design of the games to ensure that the motor and cognitive activities were in an appropriate interrelation to each other. In order to best support learning, any competitive character of the games was avoided.

To illustrate the nature of the movement games, two games, Jumping Along the Number Line and Multiplicative Relay Race, are presented here.

2 A Reversal Relay Race is a racing competition where members of a team cover the distance to a destination point one by one, complete a certain action, and run back to the next team-member.

3 The players move along the field, representing free "atoms". As soon as the facilitator announces a number, all players organize themselves in "molecules" with a group size corresponding to the number announced. 
Figure 3. Playing the Jumping Along the Number Line game.

\begin{tabular}{|c|}
\hline \multicolumn{1}{|c|}{} \\
\hline 20 \\
\hline 19 \\
\hline 18 \\
\hline 17 \\
\hline 16 \\
\hline 15 \\
\hline 14 \\
\hline 13 \\
\hline 12 \\
\hline 11 \\
\hline 10 \\
\hline 9 \\
\hline 8 \\
\hline 7 \\
\hline 6 \\
\hline 5 \\
\hline 4 \\
\hline 3 \\
\hline 2 \\
\hline $19 r t$ \\
\hline
\end{tabular}

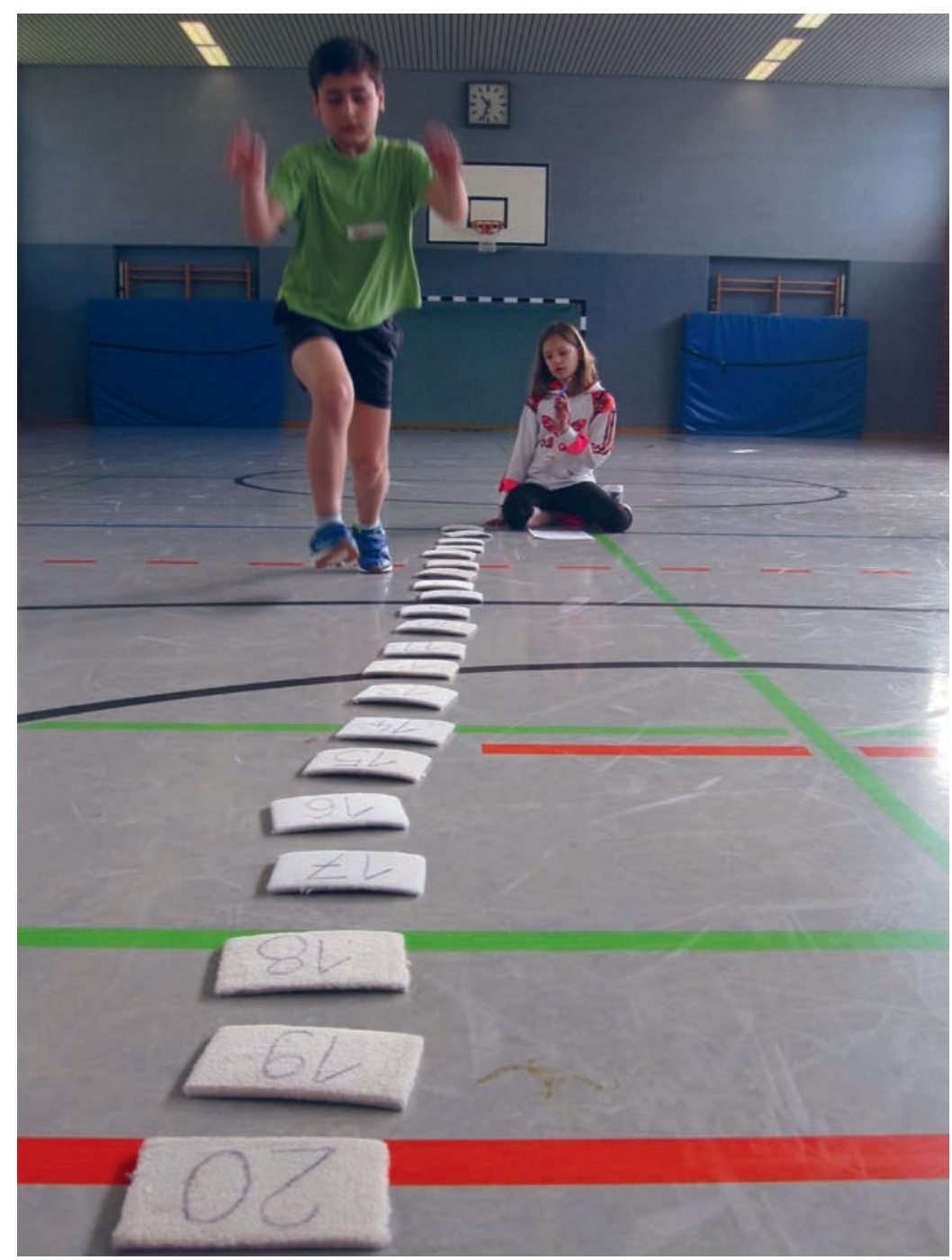

\section{Jumping Along the Number Line}

A number line was constructed from carpet tiles (10 cm x $15 \mathrm{~cm}$ ). Each tile was labelled with one number from 1 to 20 or the word "Start". ${ }^{4}$ The tiles were placed the length of one child's hand apart (see Figure 3).

4. Depending on the learning group, the use of the number "o" as starting point is recommended due to its mathematical correctness.

77 Learning Tech 04 | Fagdidaktiske studier i historie, fremmedsprog og matematik 
The students always jump with both legs. To reduce injury risk and to visualise the movement, the following four rules apply:

1. I jump next to the carpet tiles

2. I start next to the "Start" tile

3. My jumps always have the same jumping distance

4. I turn up the tiles I land next to

The students work in pairs on the following task: Student A is given a multiplication fact (e.g. "3 $3 \cdot 6$ "), but does not share it with Student B. Student A jumps, according to the secretly planned multiplication fact (e.g. jumps three times always six tiles away), and ends up next to the tile that represents the result of the multiplication fact (e.g. " $3 \cdot 6=18$ "). Student B observes the movement and describes it afterwards (e.g. "I saw you jump three times always six tiles away, so you jumped the multiplication fact $3 \cdot 6$."). The students discuss which multiplication fact was observed or which multiplication should have been jumped. They swap roles afterwards.

The jumps along the number line are structurally consistent with the iteration aspect: a similar move - making equal-distant jumps - is carried out several times in succession. While the multiplier is shown in the number of jumps (e.g. "three jumps"), the multiplicand becomes visible in the jump distance (e.g. "always six tiles"). The result of the multiplication fact is shown by the tile reached at the end of the jump, furthermore, the interim results become visible (e.g. "6, 12"). The difference between multiplier and multiplicand can be physically experienced by the different actions: it is noticeable different if someone does six jumps or the jumping distance is always six tiles. The task allows a natural differentiation because the students have the opportunity to choose the multiplication fact on their own - with respect to their physical and mathematical abilities.

The practical implementation of this game has shown that both the structure and the game idea have a highly inviting nature. The students began to move along the number line immediately after its installation. The game was well understood by the students after the teacher explained the rules and a student demonstrated it. 
Figure 4. Assembly of the Multiplicative

Relay Race game.

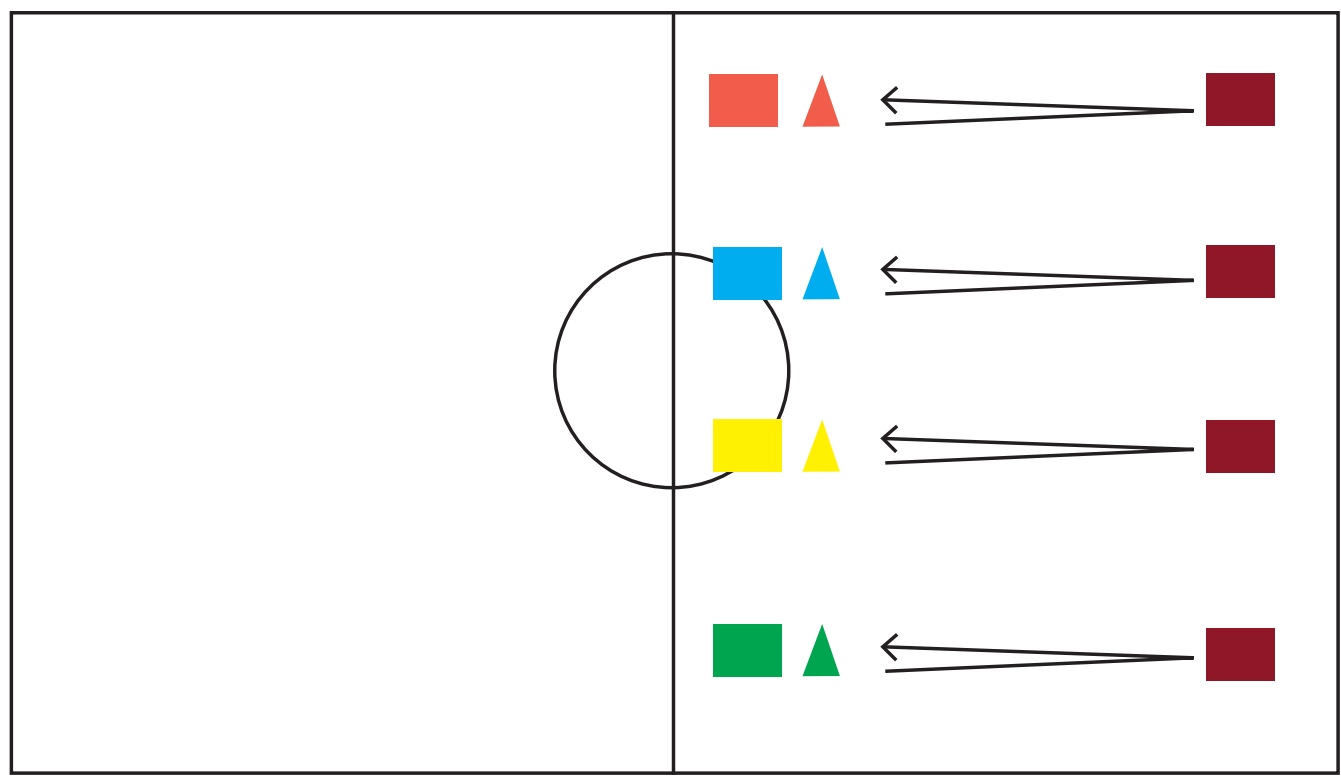

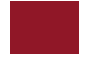

Box filled with table tennis balls

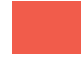

Cotton towels in a different colour for each lane

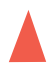

Pylon in a different colour for each lane

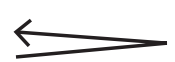

Lane for each team

\section{Multiplicative Relay Race}

The starting point of the reversal relay is marked by a pylon and a cotton towel on the ground and a box filled with table tennis balls is the turning point (see Figure 4).

The students are organized into small teams who stand in line next to the starting point. The teacher announces how many table tennis balls can be taken at a time. After the start signal, the students take turns to run one by one from the starting point to the turning point and back. The students take the same number of table tennis balls out of the box (e.g. they run and always carry three balls back). After returning, they put the balls on the cotton towel and tap hands with the next students as a starting signal for the next run. The teacher gives a signal to stop, when there are still a few table tennis balls left in the box. The students then have to find an arrangement for the table tennis balls on the 
Figure 5. Different arrangements of the groups playing the Multiplicative Relay Race game (left-hand side: always taking three balls on each run; middle and right-hand side: always taking four balls on each run).
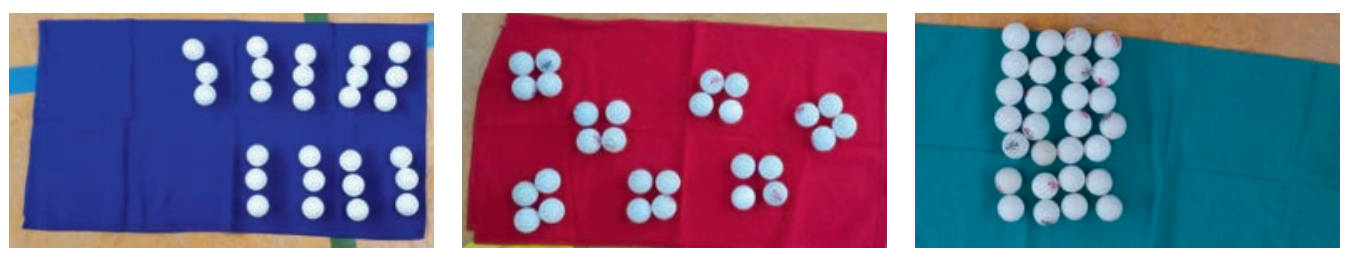

towel that enables the other students to easily identify both the number of runs and the number of balls carried on each run (for examples of formations, see Figure 5).

After positioning their own balls, the students are meant to reflect on the arrangements of the other teams individually and choose the formation in which both the number of runs of a team and the number of balls in each run can most easily be perceived. The class gathers together to discuss the formation chosen most often. By completing and discussing the worksheet together (see Figure 6) it becomes obvious that the number of ball groups shows how often the team ran, and the number of balls per group shows how many balls were carried each time.

Figure 6. Worksheet of the Multiplicative Relay Race game.

How often did the team run?

How many balls did the team always take at once?

What is the appropriate multiplication task?

What is the appropriate repeated addition task?

The repetition of the same action illustrates the iteration structure of equal groups: the students run and always carry the same number of balls. Furthermore, the requirement to arrange the 
balls in a structured formation focuses on the part-whole structure. While the multiplier is shown by the number of runs per team or in the number of subgroups of the formation, the multiplicand can be understood from in the number of balls to be picked per run or in the number of balls per subgroup. The transfer between the iteration and the part-whole structure is trained: on the one hand, by the need to arrange the balls in a part-whole structure that fits to the performed iteration action, and on the other hand, by the request to understand the part-whole structure of the other teams to be emerged by an iterated movement. There is a change of representation, as defined by Bruner (1973), from the enactive level (i.e. running and carrying the balls) to the iconic level (i.e. part-whole arrangements of the balls), as well as another change of representation from the iconic level to the symbolic level (i.e. oral interpretation of the part-whole formation and completing the worksheet in written form).

The students were highly motivated to play this game and showed perseverance in doing so. This is important because this game requires several repetitions to deepen the students' understanding and knowledge. The relationship between motor and cognitive activity emerged as particularly favourable in this game - the students could exercise intensively and enhance their mathematical abilities during the subsequent tasks.

\section{Diagnostic Tool to Evaluate Grundvorstellungen of Multiplication}

A diagnostic tool was designed to evaluate the teaching project and the effectiveness of the movement games. In particular, the diagnostic tool investigates GVs of multiplication (in terms of equal groups). Test items were based on tasks used in other studies (e.g. Hengartner \& Röthlisberger, 1999; Scherer, 2007) and were adapted to the structure and focus of the current study.

The diagnostic tool contains 13 tasks in total. Each task is presented as a visualisation of the concept on a single A6 sheet of paper. The concrete problems were given as verbal instructions. The students wrote down the result and/or, if possible, noted the calculation. The numerical values of the tasks (including the results) were limited to numbers up to 24 , as the focus is on recognizing and interpreting multiplicative situations rather than on computational skills. 
To create increasing difficulty levels the complexity of visualisation varies (Scherer, 2007, p. 10): while some items use pictorial representations that show all elements of the related number fact and, therefore, can be solved by counting (see Figure 7: task sheet [left-hand side] and verbally presented problem [right-hand side]), other items have no visualisation at all and require mental modelling or computation (see Figure 8). In addition, we created tasks with pictorial representations showing only the elements of one set; further sets have to be reconstructed mentally (see Figure 9 and Figure 10). This variety of visualisations provides options for different solution strategies for students at different levels of mathematical competency, and, therefore, allows a more detailed documentation of the learning process.

In addition, the problems were situated in different contexts in order to activate GVs of multiplication involving both partwhole and iteration structures. This enabled the evaluation of the impact of different GVs on the frequency of successful solutions and assessment of their development by the movement games. In Figure 9, the bottles are presented in a part-whole structure (four boxes with six bottles each), but in Figure 10, they are illustrated in an iteration structure (a man carries four boxes one by one with six bottles each). Both tasks are comparable as they are equal to each other in the crucial factors (using the same numerical values and the same level of visualisation (Scherer, 2007)), apart from the inherent GVs of multiplication. Thus, systematic comparisons can be made in evaluating the development of the part-whole and the iteration structure of GVs of multiplication.

Figure 7. Task sheet showing all elements.

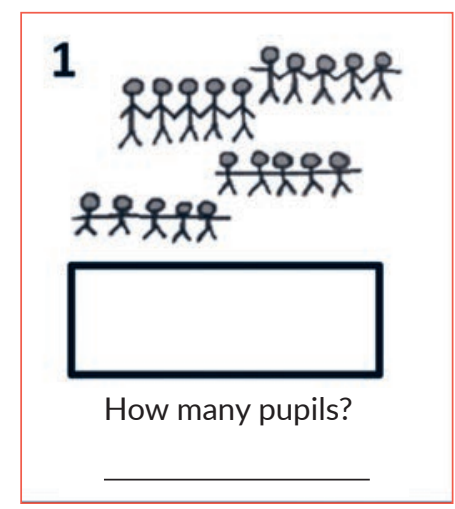

In the picture you see four groups of five pupils each.

How many pupils are there in total?

Write the result on the line.

Write your calculation in the box. 
Figure 8. Task sheet showing no elements.

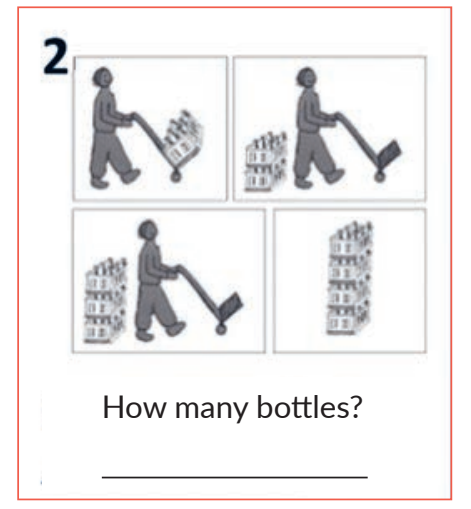

In the picture you see a man carrying four times always six bottles.

How many bottles does the man carry in total?

Write the result on the line.

Figure 9. Task sheet showing the elements of one set in a part-whole structure.

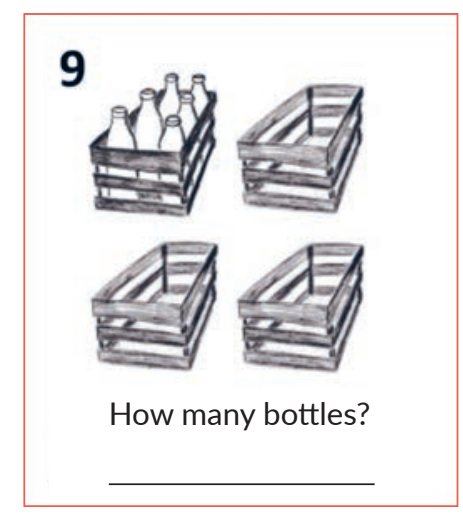

In the picture you see a box with six bottles. In total, there are four boxes, each box with alway six bottles.

How many bottles fit in the boxes in total?

Write the result on the line.

Figure 10. Task sheet showing the elements of one set in an iteration structure.

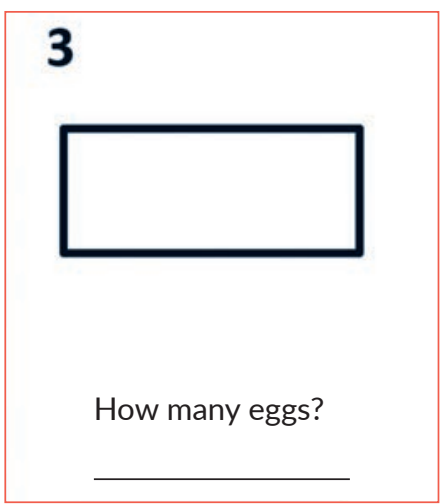

Listen carefully. You do not see a visualization of the task right now. Imagine: There are three egg crates, each egg crate with always six eggs.

How many eggs are there in total?

Write the result on the line.

Write your calculation in the box.

83 Learning Tech 04 | Fagdidaktiske studier i historie, fremmedsprog og matematik 


\section{Results}

Regarding the exploratory design of the study, it becomes obvious that the results are only generalizable to a limited extent. Nevertheless, the findings can be seen as first indicators for the effectiveness of the designed movement games and subsequently of Learning through Physical Activity.

The results both of the pre- and post-test and the participatory observations indicate a development of GVs of multiplication. Compared to the pre-test the students solved 22 more tasks correctly in the post-test (corresponding to an increase of $9,4 \%)^{5}$. However, differences within the sample of students were noticed, with a range from two tasks less up to five correct tasks more with correct results in the post-test. Figure 11 illustrates the students' intra-individual development in terms of the number of correct answered tasks from pre- to post-test.

Figure 11. Intra-individual development of each student in term of his/her respective number of tasks with correct results from pre- to post-test.

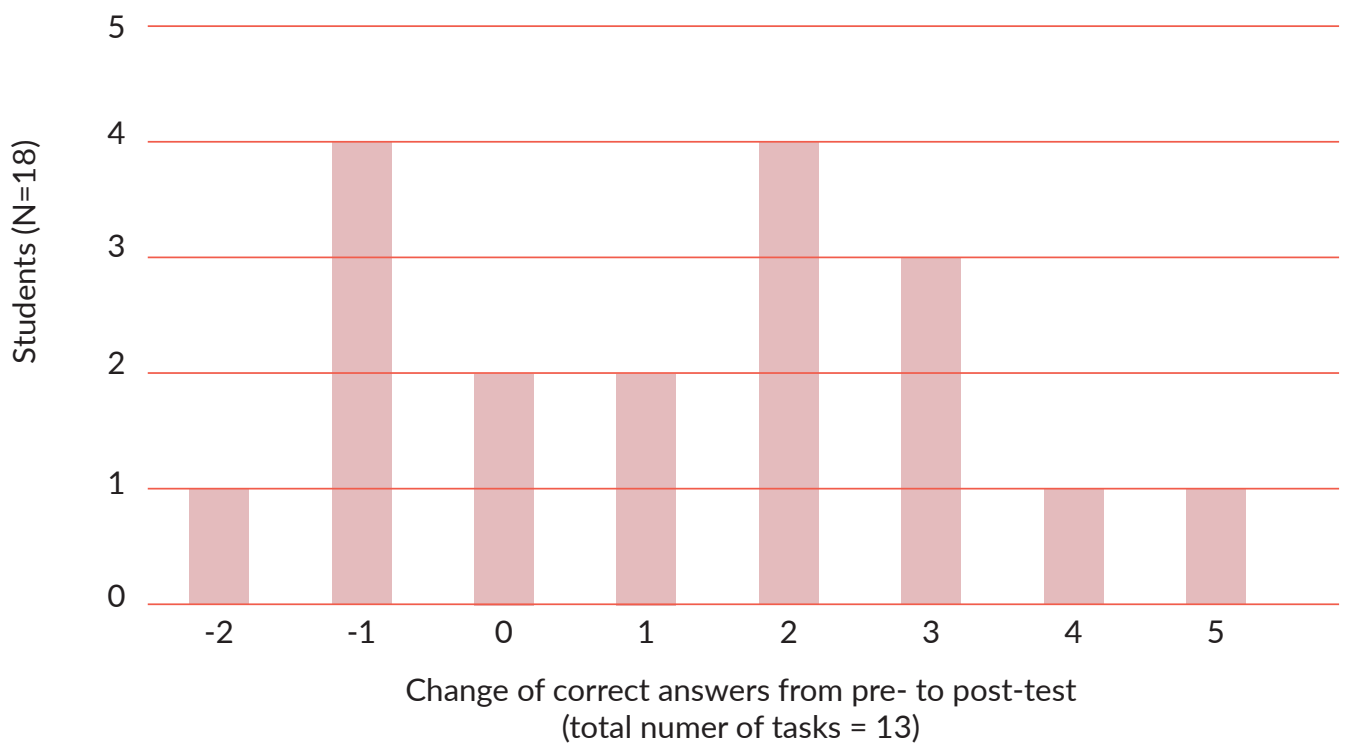

5 To ensure better comparability of results, both pre- and post-test contain identical tasks. Due to the time difference between the two tests of two weeks and the fact, that similar tasks have not been used in the intervention, no recognition effects by the students are to be expected. 
While five students answered fewer tasks correctly in the posttest than in the pre-test, two students solved the same number of tasks successfully. 11 out of 18 students were able to deal with an increasing number of tasks successfully. Furthermore, positive changes in the number of tasks with correct results show more variance $(+1$ to +5 tasks) than negative changes ( -1 to -2 tasks). With respect to the first research question ("To what extent does Learning through Physical Activity influence GVs of multiplication?"), this indicates an increase in conceptual learning among some students. Taking into account the limited intervention time and the fact that the games were conducted by a less experienced teacher with a relatively unknown learning group, greater effectiveness can be assumed in another learning environment.

In analysing the impact of different GVs on the frequency of correct results, it appears that the students answered tasks with a part-whole structure correctly more frequently in the post-test. In contrast, the success rate in tasks with an iteration structure remained nearly unchanged (see Figure 12). Moreover, the results showed that the tasks with a part-whole structure were handled correctly nearly twice as often as the tasks with an iteration structure. An error analysis of the incorrect answers explains this salience. One reason seems to lie in the ambiguity of pictorial representations, especially for illustrating iterative processes, rather than the students' lack of understanding. The most commonly given answer for the task was "60", as shown in Figure 10. This is the correct answer if a student looks at the picture as a whole (ten boxes with six bottles each given in all four pictures together) and not as an iterative process (carrying one box with six bottles four times). The difficulty in properly interpreting such illustrations is also described in literature (Bönig, 1995; Lorenz, 1998). Therefore, no meaningful results can be given regarding the development of the iteration structure of GVs.

To answer the second research question ("To what extent does the identified development also apply to students with learning difficulties in mathematics?"), the mathematics teacher was asked to classify her students into two groups, based on the students' current performance in written assignments: those with learning difficulties in mathematics (seven students) and those without (eleven students). In general, no "ceiling effect" could be determined in the whole sample. Two students with learning difficulties answered fewer tasks correctly in the posttest, while five out of seven students in this group succeeded in a larger number of tasks (see Figure 13). 
Figure 12. Distribution of solved tasks

in the post-test, taking into account

part-whole and iteration structure.

Iteration structure (3 tasks)

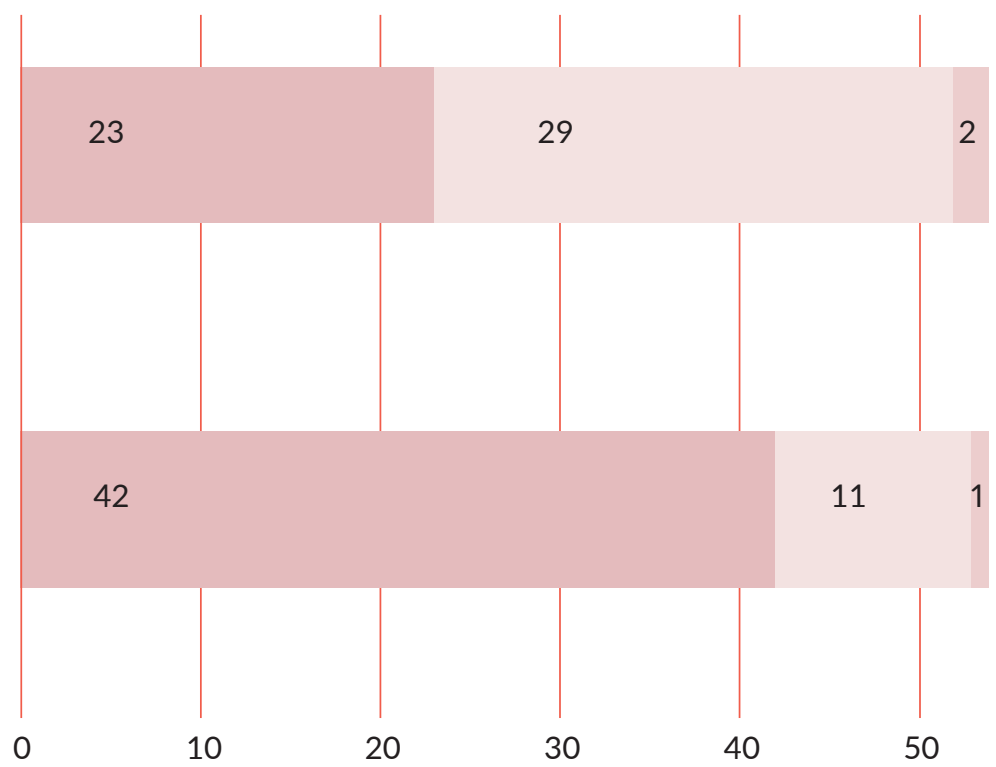

Part-whole structure (3 tasks)

42

20

30

False result
Correct result
Fesult
1

No result

Even the most significant growth in the number of correctly answered items $(+5)$ was achieved by a student with difficulties in learning mathematics. Within the group of students without difficulties in learning mathematics, with six out of eleven, a lower proportion of students succeeded in an increasing number of tasks in the post-test, compared to the group of students with difficulties in learning mathematics. In addition, three students answered fewer tasks correctly. The students without learning difficulties solved an average of 1.0 more tasks in the post-test; those with learning difficulties improved by 1.6 tasks. These findings provide a basis for the assertion that some students with learning difficulties benefit from learning environments with whole-body movements that correspond structurally to the mathematical learning content. Based on these results, implementing Learning through Physical Activity can be considered as a promising method for students, particularly for students with difficulties in learning mathematics. 
Figure 13. Intra-individual development of each student in terms of his/her respective number of tasks with correct results from pre- to post-test, taking into account students with and without learning difficulties in mathematics.

5

4

3

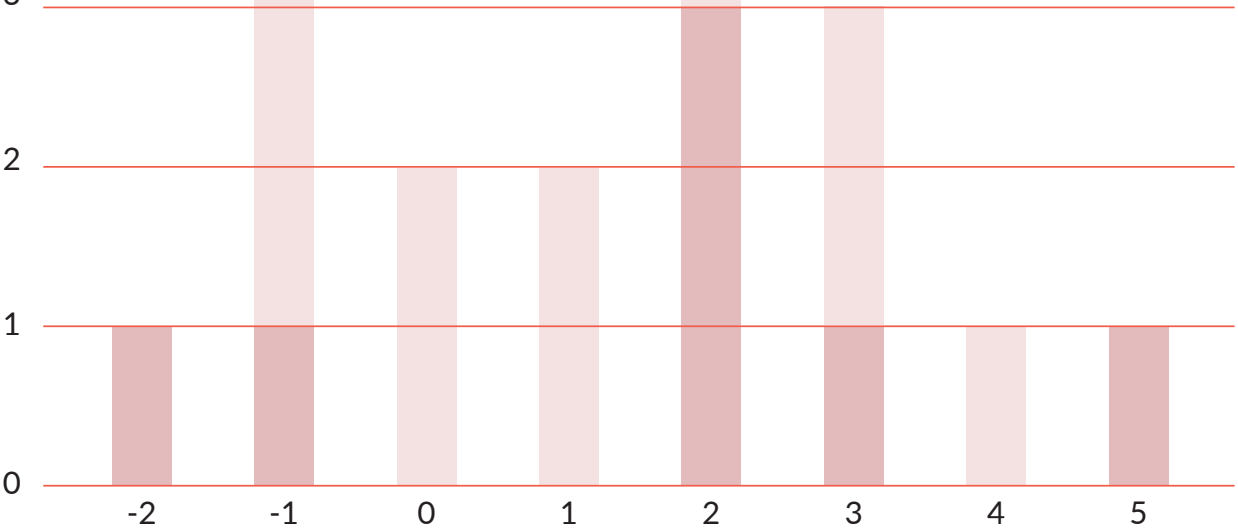

Change of correct answers from pre- to post-test (total numer of tasks $=13$ )

Students with learning difficulties in mathematics $(\mathrm{N}=7)$

Students without learning difficulties in mathematics $(N=11)$

\section{Discussion and Implication for Further Teaching Studies}

This exploratory study aims at building the foundation for further research by identifying relevant factors for implementing and evaluating Learning through Physical Activity in mathematics education. Hence, the findings are reflected upon conclusions that can be drawn for further teaching studies.

The findings of the study indicate a positive influence of Learning through Physical Activity. However, the design of the study cannot conclusively clarify to what extent the results are 
influenced by confounding factors such as variation in the daily form or recognition of tasks in the diagnostic tool. Therefore, further studies should include a larger sample as well as control groups (without any content related training and/or with training of GV of multiplication but without any movement).

As the findings of the exploratory study indicate a comparatively high improvement among students with difficulties in learning mathematics, but with considerable individual differences within this sample, it seems worthwhile to focus on this group of students in further studies. Complementary individual interviews and a modification of both diagnostic tool and movement games in order to focus on a conceptual understanding of multiplication instead of computational competencies might provide deeper insights into their GVs of multiplication.

\section{Recommended Modifications}

On review of the results and experiences from the study, two major modifications are proposed. Both modifications influence the structure of the diagnostic tool, the movement games and the discussion of the movement.

The first modification is to set the focus on the matching number fact for a given situation - not on its arithmetical result. An analysis of the concrete results of the diagnostic tool has shown that incorrect results are not necessarily caused by missing multiplicative knowledge, but rather by a lack of arithmetical skills (e.g. counting mistakes, not understanding place value). Furthermore, if only the correct result is determined (e.g. in identifying the number of bottles in four boxes; see Figure 9), this does not ensure that the student is adequately interpreting the situation as being multiplicative. Counting (i.e. mental) strategies can be used successfully, even if a student does not perceive the inherent multiplicative structure. Therefore, asking for the matching number fact focuses more on GVs of multiplication than of performing (multiplicative) calculations.

Accordingly, some modifications were made to the tasks in the diagnostic tool. An enhanced version asks for the matching number fact only and not for the arithmetical result (see Figure 14). Furthermore, a new task type was added in which the students have to choose the appropriate number facts for a pictorial representation from a multiple-choice question (see Figure 15). The given number facts were selected to gain essential informa- 
tion about students' understanding of multiplication, as well as about possible misconceptions. In addition, these types of tasks are useful because they provide assistance for weaker students through the given answer options.

Figure 14. Revised task sheet, focusing on the matching number fact.

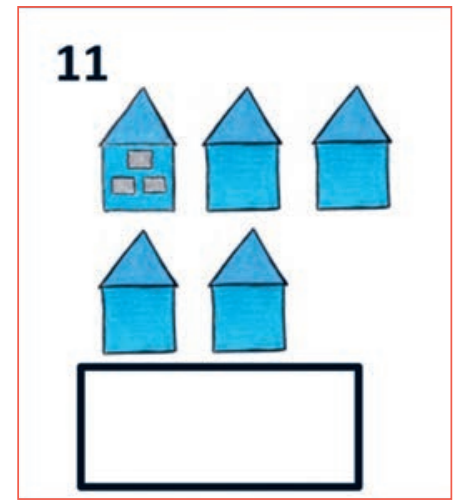

In the picture you see a house with three windows. In total, there are five houses with always three windows.

Write your calculation in the box.

Figure 15. New task type including prescribed number facts.

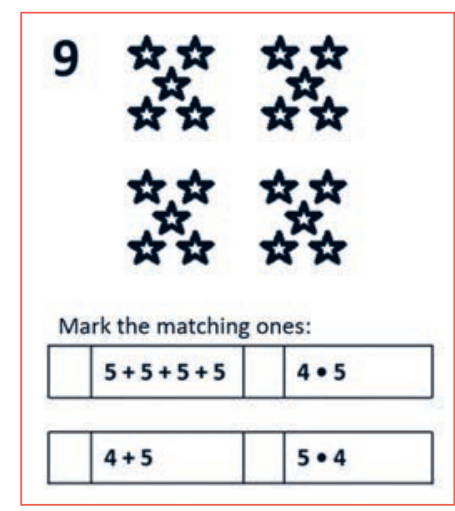

Mark the number facts that fit to the picture. One, two, three or four number facts can be right.

This modification influences how the movement games are led. In conducting the games, and in the corresponding verbal direction, special emphasis should be placed on the matching number fact - not on the result. This can be supported by systematically referring to written multiplication facts after conducting a move- 
ment. A modification of the Multiplicative Relay Race game aims to deepen the meaning of the written number fact in relation to the movement. The core game is played as previously described, except that every team is given a card with a different task in the form of an incomplete number fact, "_. 3 ", which must be completed at the end of the relay race. The relay race starts with each team performing an action corresponding to the given task, in this example, always taking three table tennis balls per run. After positioning the balls, the team completes the number fact “__ 3 " by filling in the multiplier. In this game variant, the answers of all the teams are discussed together as a class. Looking at the teams' table tennis ball arrangements, the students have to work out the given task of each group, as well as the completed number fact they produced. The game variation can be extended by varying the tasks on the cards: by asking for the multiplier (e.g. " $3 \cdot \ldots$-_); by a complete specification of the task (e.g. "3 $3 \cdot 4$ "); or by giving no specification at all (e.g. “__ • ”).

According to Gaidoschik (2015, p. 45), realising differences in the meaning of a number fact (e.g. " $3 \cdot 6$ ") and its commutative number fact (e.g. " $6 \cdot 3$ ") is crucial for the acquisition of GVs of multiplication, despite both facts having the same result. Hence emphasizing the distinction between the number fact and commutative number fact is the second modification needed for the further development of the study. In the enhanced version of the diagnostic tool, this aspect is implemented in the new task type, as illustrated in Figure 15. In these tasks, students must select the matching number fact from a set of pictorial representations. Both the corresponding and the commutative number fact are included in the given choices. To foster students' GVs and to raise awareness of the difference, the focus should be on the distinction of both tasks. The Jumping Along the Number Line game is particularly suitable to develop and train understanding. The difference between both tasks can be directly perceived with the whole body: either you jump three times always six tiles away or you jump six times always three tiles away. The movement considerably differs for both tasks, consequently, the movement helps students to differentiate both tasks and to develop GVs of multiplication. 


\section{Summary and Conclusion}

The movement games have proven themselves in an inclusive learning group by setting adequate challenges for all students, regardless of their level of motor skills and mathematical competences. All students were able to play the games successfully and with great enjoyment. Moreover, because of the lack of competition, students were not interdependent in their actions, so there was no discrimination against weaker students.

Based on the described results, further work on two levels seems to be promising. First, it is necessary to develop more movement games to support learning of different mathematical contents through physical activity. Currently, the potential of Learning through Physical Activity in school practice is barely used. Repetition of the movement games and their implementation in regular school life can be expected to have an even greater impact on the learning process.

Second, the study indicates that further research on the evaluation of Learning through Physical Activity in mathematics education is needed. In particular, the suggested game modifications should be carried out with larger samples in order to validate the observed learning developments. Special emphasis should be placed on reflecting the inherent features of the mathematical concept in the movement performed in the games.

Finally, we would like to point out that interdisciplinary cooperation between mathematics didactics and sports pedagogy was very effective and expedient in this research project. In accordance with this experience further cooperation is recommended.

\section{References}

Baur-Fettah, Y. (2007). Lernen durch Bewegung - eine Chance zu erkennen, zu erfahren, zu begreifen und zu verstehen. In R. HildebrandtStramann (Ed.), Bewegte Schule: Schule bewegt gestalten (pp. 182-194). Baltmannsweiler: Schneider-Verl. Hohengehren.

Barmby, P., Harries, T., Higgins, S., \& Suggate, J. (2009). The array representation and primary children's understanding and reasoning in multiplication. Educational Studies in Mathematics, $70(3), 217-241$. DOI: 10.1007/s10649-008-9145-1.

Beckmann, H., \& Riegel, K. (2014). Bewegtes Lernen! Mathe 1.-4. Klasse (2. Aufl.). Donauwörth: AAP Lehrerfachverlage.

Bönig, D. (1995). Multiplikation und Division. Internationale Hochschulschriften; 155. Münster [u.a.]: Waxmann. DOI: 10.1007/bfo3339311 
Bruner, J. S. (1966). Toward a theory of instruction. Cambridge: Harvard University Press. DOI: 10.1177/019263656605030929

Bruner, J. S. (1973). The growth of representational processes in childhood. In J. M. Anglin (Ed.), Jerome S. Bruner: Beyond the information given (pp. 313-324). New York: Norton.

Downton, A., \& Sullivan, P. (2017). Posing complex problems requiring multiplicative thinking prompts students to use sophisticated strategies and build mathematical connections. Educational Studies in Mathematics, 95(3), 303-328. DOI: 10.1007/s10649-017-9751-x

Fleig, P. (2008). Der Zusammenhang zwischen körperlicher Aktivität und kognitiver Entwicklung - Theoretische Hintergründe und empirische Ergebnisse. Sportunterricht, 57, 11-16.

Gaidoschik, M. (2015). Einmaleins verstehen, vernetzen, merken. Strategien gegen Lernschwierigkeiten. Seelze: Klett Kallmeyer.

Greer, B. (1992). Multiplication and division as models of situations. In D. A. Grouws (Ed.), Handbook of research on mathematics teaching and learning (pp. 276-295). New York: Macmillan.

Hengartner, E., \& Röthlisberger, H. (1999). Standortbestimmungen zum Einmaleins (2. Klasse): Die Suche nach geeigneten Aufgaben. In E. Hengartner (Ed.), Mit Kindern lernen. Standorte und Denkwege im Mathematikunterricht (pp. 36-40). Zug: Klett und Balmer.

Kleine, M., Jordan, A., \& Harvey, E. (2005). With a focus on, 'Grundvorstellungen' - Part 1: a theoretical integration into current concepts. ZDM - Mathematics Education, 37(3), 226-233. DOI: 10.1007/s11858oo5-0013-5

Larsson, K., Pettersson, K., \& Andrews, P. (2017). Students' conceptualisations of multiplication as repeated addition or equal groups in relation to multidigit and decimal numbers. Journal of Mathematical Behavior, 48, 1-13. DOI: 10.1016/j.jmathb.2017.07.003

Link, T., Moeller, K., Huber, S., Fischer, U., \& Nuerk, H.-C. (2015). Corrigendum to "Walk the number line - An embodied training of numerical concepts" [Trends in Neuroscience and Education, 2(2), 74-84, (2013)]. Trends in Neuroscience and Education, 4(4), 112. DOI: 10.1016/j.tine.2015.11.003

Lorenz, J. H. (1998). Anschauung und Veranschaulichungsmittel im Mathematikunterricht. Mentales visuelles Operieren und Rechenleistung. Göttingen, Bern, Toronto, Seattle: Hogrefe.

McNeil, N., \& Uttal, D. (2009). Rethinking the use of concrete materials in learning: Perspectives from development and education. Child Development Perspectives, 3(3), 137-139. DOI: 10.1111/j.1750-8606.2009.00093.x

Müller, C. (Ed.) (2003). Bewegtes Lernen in Klasse 1 (2. neu bearb. Aufl.). St. Augustin: Academia Verlag.

Piaget, J. (1970). Science of education and the psychology of the child. New York: Orion Press.

Rasberry, C. N., Lee, S. M., Robin, L., Laris, B. A., Russell, L. A., Coyle, K. K., \& Nihiser, A. J. (2011). The association between school-based physical activity, including physical education, and academic performance: A systematic review of the literature. Preventive Medicine, 52 (1), 10-20. DOI: 10.1016/j. ypmed.2011.01.027

Scherer, P. (2007). Produktives Lernen für Kinder mit Lernschwächen. (n.d.). Band3: Multiplikation und Division im Hunderterraum. Bergedorfer Förderdiagnostik (2. Aufl.). Leipzig [u.a.]: Klett-Grundschulverlag. 
Schmidt, S., \& Weiser, W. (1995). Semantic structures of one-step word problems involving multiplication or division. Educational Studies in Mathematics, 28(1), 55-72. DOI: 10.1007/bfo1273856

Sibley, B. A., \& Etnier, J. L. (2003). The relationship between physical activity and cognition in children: A meta-analysis. Pediatric Exercise Science, 15(3), 243-256. DOI: 10.1123/pes.15.3.243

Simon, M., Saldanha, L., McClintock, E., Akar, G. K., Watanabe, T., \& Zembat, I. O. (2010). A developing approach to studying students' learning through their mathematical activity. Cognition and Instruction, 28(1), 70-112. DOI: 10.1080/07370000903430566

Thiel, A., Teubert, H., \& Kleindienst-Cachay, C. (2006). Die "Bewegte Schule" auf dem Weg in die Praxis (3. überarb. Aufl.). Baltmannsweiler: SchneiderVerlag. Hohengehren.

Tran, C., Smith, B., \& Buschkuehl, M. (2017). Support of mathematical thinking through embodied cognition: Nondigital and digital approaches. Cognitive Research: Principles and Implications, 2(16), 1-18. DOI: 10.1186/ S41235-017-0053-8

Tzur, R. (2007). Fine grain assessment of students' mathematical understanding: participatory and anticipatory stages in learning a new conception. Educational Studies in Mathematics, 66(3), 273-291. DOI: 10.1007/ S10649-007-9082-4

Uttal, D., Scudder, K., \& DeLoache, J. (1997). Manipulatives as symbols: a new perspective on the use of concrete objects to teach mathematics. Journal of Applied Developmental Psychology, 18(1), 37-54. DOI: 10.1016/so1933973(97)90013-7

Uttal, D., O'Doherty, K., Newland, R., Liu Hand, L., \& DeLoache, J. (2009). Dual representation and the linking of concrete and symbolic representations. Child Development Perspectives, 3 (3), 156-159. DOI: 10.1111/j.17508606.2009.00097.x

Voll, S., \& Buuck, S. (2005). Steigerung der geistigen Leistungsfähigkeit durch Bewegung. In E. Wutz, H. Vorleuter \& H. Resper (Eds.), Schulsport: Vorschriften, Empfehlungen und Unterrichtshilfen für den Sportunterricht und außerunterrichtlichen Schulsport (pp. 1-6). Köln: Carl Link Verlag.

vom Hofe, R., \& Blum, W. (2016). „Grundvorstellungen“ as a category of subject-matter didactics. Journal für Mathematikdidaktik, 37(Suppl. 1), 225-254. DOI: 10.1007/s13138-016-0107-3

Wartha, S. (2011). Handeln und Verstehen. Förderbaustein: Grundvorstellungen aufbauen. Mathematik lehren, 166, 8-14.

Weidenmann, B. (2009). Multimedia, Multicodierung und Multimodalität beim Online-Lernen. In L. Issing \& P. Klimsa, Online-Lernen: Handbuch für Wissenschaft und Praxis (pp. 73-86). München: Oldenbourg. DOI: 10.1524/9783486710175.71

Young-Loveridge, J., \& Mills, J. (2009). Teaching multi-digit multiplication using array-based materials. In R. Hunter, B. Bicknell, \& T. Burgess (Eds.), Crossing divides: Proceedings of the $32^{\text {nd }}$ annual conference of the Mathematics Education Research Group of Australasia (pp. 635-642). Palmerston North, NZ: MERGA. 


\section{Learning Tech - Tidsskrift for læremidler, didaktik og teknologi Udgives af Læremiddel.dk}

Learning Tech er et forskningstidsskrift, hvor alle artikler er forskerbedømt i form af dobbeltblindt peer review. Tidsskriftet bringer artikler, der rammer genstandsfeltet mellem læremidler, didaktik og teknologi, og hensigten er at spille en betydelig rolle som platform for den voksende skandinaviske læremiddelforskning.

\section{Redaktion}

Thomas R.S. Albrechtsen, University College Syd (ansvarshavende redaktør) Anne-Mette Nortvig, Professionshøjskolen Absalon Bettina Buch, Professionshøjskolen Absalon Hildegunn Juulsgaard Johannesen, University College Syd Marie Falkesgaard Slot, UCL Erhvervsakademi og Professionshøjskole René Boyer Christiansen, Professionshøjskolen Absalon Stefan Ting Graf, UCL Erhvervsakademi og Professionshøjskole Stig Toke Gissel, UCL Erhvervsakademi og Professionshøjskole Stine Reinholdt Hansen, UCL Erhvervsakademi og Professionshøjskole

\section{Redaktionssekretær}

Trine Ellegaard, UCL Erhvervsakademi og Professionshøjskole

\section{Temaredaktion}

Thomas R.S. Albrechtsen, University College Syd

Marie Falkesgaard Slot, UCL Erhvervsakademi og Professionshøjskole Hildegunn Juulsgaard Johannesen, University College Syd

\section{Design og grafisk tilrettelæggelse}

Trefold - grafisk design og kommunikation

\section{Tryk}

Grafisk Produktion Odense

ISSN 2445-7981 (Tryk)

ISSN 2445-6810 (Online)

\section{Rettigheder}

(c) 2018 Læremiddel.dk og forfatterne

\section{Kontakt}

Læremiddel.dk, Niels Bohrs Allé 1, 523o Odense M

www.laeremiddel.dk 